\title{
INSULIN-LIKE GROWTH FACTOR I STIMULATES TRANSCRIPTION OF THE $C$-JUN PROTO-ONCOGENE IN BALB/C 3T3 CELLS
}

\author{
Shean-Tai Chiou ${ }^{1}$ and Wen-Chang Chang 1, 2 *
}

1 Institute of Biochemical Sciences, National Taiwan University, and

2 Institute of Biological Chemistry, Academia Sinica, P.0. Box 23-106 Taipei, Taiwan, R.O.C.

Received January 21, 1992

Treatment of quiescent Balb/c 3T3 cells with insulin-like growth factor I (IGF I) resulted in the stimulation of proto-oncogene $c$-jun transcription. Cells exposed to cycloheximide and IGF I together showed super-induction of $c$-jun transcripts. Nuclear run-off assay revealed that IGF I up-regulated $c$-jun only while cycloheximide was present. The stability of $c$-jun mRNA was markedly increased in the cells treated with IGF I. These results suggest that IGF I controls the expression of $c$-jun by increasing the transcriptional activity and stabilizing the existing transcripts. 1992 Academic Press, Inc.

Insulin-like growth factor I (IGF I) was first identified as a cationic polypeptide from human serum with cell division stimulating capacity for Balb/c $3 T 3$ cells $(1,2)$. The growth factor contains single polypeptide chain with 70 amino acid residues which displays obvious homology to proinsulin (3). In vivo, IGF I stimulates growth in hypophysectomized rats, suggesting that IGF I mediate the action of growth hormone, according to somatomedin hypothesis $(4,5)$. Regulations of cellular growth in different tissues, such as the regulation of embryogenesis, were suggested to be exerted by coordination of several growth factors (6-10).

Many oncogenes, such as fos, jun, myc, rel, erbA, and $m y b$, encode nuclear proteins which contain DNA binding abilities or act as transcription factors (11). Moreover, several of these oncogenes are rapidly expressed in quiescent cells treated with mitogens. These are immediate early genes or primary response genes (12-16). Recently, many primary response genes were found to play essential roles in cell proliferation and differentiation $(15,16)$.

\footnotetext{
To whom correspondence should be addressed.
} 
The proto-oncogene $c$-jun is a cell-derived sequence that was first identified as the oncogene of avian sarcoma virus 17 (ASV-17), which neoplastically transforms chick embryo fibroblasts $(17,18)$. Further characterization indicated that $c$-jun encodes the transcription factor AP-1 or a closely related protein $(17,18)$. It has been proposed that rapid increase in expression of immediate early gene such as $c$-jun is an important mechanism to establish the long-term transcriptional response of cells to growth factors (14).

It is well known that the receptor for IGF I exhibits high degree of structural and functional homology with that of insulin (19). After growth factor binding, the receptors undergo autophosphorylation and enhancement of their tyrosine kinase activity (20). The possible substrates for the receptor tyrosine kinase include some insoluble cytoskeletonassociated protein pp175 (21) and the cellular protein pp185 which was phosphorylated within 10 seconds after IGF 1 or insulin binding to their respective receptor (22). It is believed that activation of normal p21 H-ras, a member of $\mathrm{G}$ protein family, may be involved in the signal transduction pathway of IGF I stimulation $(20,23)$. In the cell nucleus, it has been reported that IGF I caused an elevation of $c$-fos transcripts in L6 cells (24). However, the linkage between intracellular signal tranmission and cell proliferation in the mechanism of IGF I action remains to be established.

Since fos protein is responsible for transcription regulation by means of heterodimer formation with c-jun/AP-1, genes which contain AP-1 binding site in the promoter region, such as collagenase or metallothionein gene, can be regulated by fos-jun complex $(25,26)$. To test whether fos-jun heterodimer is involved in the signal transduction pathway of IGF I stimulation, we examined the transcription levels of $c$-jun after quiescent cells were stimulated by IGF I. We propose herein that IGF I have dual functions in $c$-jun stimulation, namely stabilization of the existing transcripts and enhancement of the transcription activity.

\section{MATERIALS AND METHODS}

Cell culture. Balb/c 3T3 (clone A31) cells were obtained from American Type Culture Collection. Cells were grown in DMEM (Dulbecco's modified Eagle's medium) with $10 \%$ calf serum. For growth factor stimulation experiments, cells were grown to confluency and then placed in DMEM / F12 (1:1) with bovine serum albumin (1mg/ml), transferrin (50 $\mu \mathrm{g} / \mathrm{ml})$, soybean lipid $(8 \mu \mathrm{g} / \mathrm{ml})$ and sodium selenite $\left(3 \times 10^{-8} \mathrm{M}\right)$ for 24 hours. Cells were stimulated by the addition of IGF I $(25 \mathrm{ng} / \mathrm{ml}$, human recombinant, Boehringer Mannheim), cycloheximide (10 $\mu \mathrm{g} / \mathrm{ml}$, Boehringer Mannheim), or IGF I plus 
cycloheximide, and harvested at $30,60,90,120$ minutes after stimulation as indicated. For RNA stability assay, quiescent cells were treated with actinomycin D $(1 \mu \mathrm{g} / \mathrm{ml}$, Sigma) for 15 minutes prior to the administration of growth factor. The level of $c-j u n$ mRNA was then analysed by Northem blotting (27). All chemicals for cells culture are purchased from Boehringer Mannheim or Sigma.

Plasmids. The plasmid pSV-jun containing cDNA of $c$-jun was used to prepare labeled probes as described (28). PstI fragment of rat glyceraldehyde-3-phosphate dehydrogenase (GAPDH) gene (29) subcloned into pGEM-3Z was used as internal control.

Northern blotting. Total RNA was isolated by the guanidinium/cesium chloride centrifugation method (42). Twenty $\mu \mathrm{g}$ of total RNA were electrophoretically seperated through formaldehyde/ $0.9 \%$ agarose gel and transferred to nylon membranes by standard protocol (43). RNA was immobilized to the membrane by UV crosslinking at 1.2 $\mathrm{J}$. The membranes were prehybridized in hybridization buffer ( $50 \%$ deionized formamide, 5X Denhardt's solution, $5 X$ SSPE, $0.2 \%$ SDS and $100 \mu \mathrm{g} / \mathrm{ml}$ denaturated salmon sperm DNA, $1 \mathrm{X}$ SSPE $=0.15 \mathrm{M} \mathrm{NaCl}, 0.01 \mathrm{M} \mathrm{NaH}_{2} \mathrm{PO}_{4}, 1 \mathrm{mM}$ EDTA $p \mathrm{H} 7.4$ ) at $42^{\circ} \mathrm{C}$ for 2 hours. The heat denatured, random primer labelled $1.8 \mathrm{~kb} c$-jun fragment from clone $\mathrm{pSV}$ jun was added to hybridization buffer and hybridization was performed for 20 hours at $42^{\circ} \mathrm{C}$. The membranes were washed for 30 minutes with $5 X$ SSPE plus $0.1 \%$ SDS at room temperature and 30 minutes with 1 XSSPE plus $0.1 \%$ SDS at $37^{\circ} \mathrm{C}$, then finally with $0.1 \mathrm{XSSPE}$ plus $0.1 \%$ SDS at $65^{\circ} \mathrm{C}$ for 30 minutes. Autoradiograms were obtained by exposing $\mathrm{X}$-ray films at $-70^{\circ} \mathrm{C}$ with intensifying screens.

Nuclear run-off assay. Isolation of Balb/c 3T3 nuclei and run-off transcription are performed as described by Greenberg et al (12) with slight modification. For each run-off transcription assay, $5 \times 10^{7}$ cells were starved for 24 hours in DMEM/F12 (1:1) as described in Cell culture section. After 30 minutes of IGF I stimulation, cells were washed twice with ice-cold PBS (phosphate buffered saline) and harvested by scraping with cell scrapper. Cycloheximide treatments were performed at 1 hour before addition of IGF I. Cells were then lysed by gentle vortexing with NP-40 lysis buffer $(10 \mathrm{mM}$ Tris $\bullet \mathrm{Cl} p \mathrm{H} 7.4$, $10 \mathrm{mM} \mathrm{NaCl}, 3 \mathrm{mM} \mathrm{MgCl} 2$, and $0.5 \%$ Nonidet $P-40$ ) and nuclei were harvested by centrifugation at $500 \mathrm{Xg}$ for 5 minutes at $4^{\circ} \mathrm{C}$. The lysis and centrifugation procedures were repeated once to ensure uniform lysis of the cells. Nuclei pellets were then suspended in

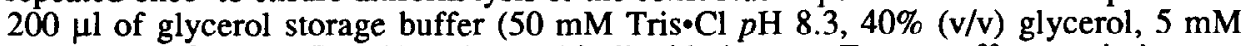
$\mathrm{MgCl}_{2}$, and $0.1 \mathrm{mM}$ EDTA) and stored in liquid nitrogen. For run-off transcription, we thawed $200 \mu \mathrm{l}$ of frozen nuclei at room temperature. RNA synthesis reactions were carried out at $30^{\circ} \mathrm{C}$ for 30 minutes, with $5 \mathrm{mM}$ Tris $\cdot \mathrm{Cl} p \mathrm{H} 8.0,2.5 \mathrm{mM} \mathrm{MgCl}, 150 \mathrm{mM} \mathrm{KCl}, 2.5$ $\mathrm{mM}$ DTT, $0.5 \mathrm{mM}$ ATP, $0.5 \mathrm{mM}$ CTP, $0.5 \mathrm{mM}$ GTP, $0.6 \mu \mathrm{M}$ UTP and $100 \mu \mathrm{Ci}[\alpha-$ 32PJUTP (3000 Ci/mmol, Amersham). The reaction was terminated by digestion with RNase-free DNase I and proteinase K, and subsequently extracted with phenol/chloroform. Radioactive labelled RNA were isolated as described elsewhere (44). Before ethanol precipitarion, [32P]-labelled RNA was treated with a final concentration of $0.2 \mathrm{M} \mathrm{NaOH}$ for $10 \mathrm{~min}$ on ice. The solution was neutralized by the addition of HEPES (free acid) to a final concentration of $0.24 \mathrm{M}$ and the RNA was precipitated with ethanol at $-20^{\circ} \mathrm{C}$ overnight. After centrifugation, the [32P]-labelled RNA pellet was resuspended in TES

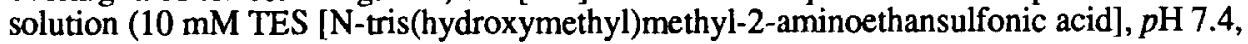
$10 \mathrm{mM}$ EDTA, and $0.2 \%$ SDS) at $5 \times 10^{6}$ c.p.m. $/ \mathrm{ml}$. This RNA solution was mixed with equal volume of TES/ $\mathrm{NaCl}(10 \mathrm{mM}$ TES, $p \mathrm{H} 7.4,10 \mathrm{mM}$ EDTA, $0.2 \% \mathrm{SDS}$, and 600 $\mathrm{mM} \mathrm{NaCl}$ ), and $2 \mathrm{ml}$ of the RNA solution was hybridized at $65^{\circ} \mathrm{C}$ for 36 hour to DNA immobilized on nitrocellulose. In a given experiment, each filter was hybridized with [32P]-labelled RNA of the same c.p.m. After the hybridization reaction, the filters were washed with 2XSSPE for 2 hours at $65^{\circ} \mathrm{C}$ and incubated at $37^{\circ} \mathrm{C}$ in $2 X S S P E$ with 10 $\mu \mathrm{g} / \mathrm{ml}$ RNase A for 30 minutes. Finally, the filters were washed with 2 X SSPE at $37^{\circ} \mathrm{C}$ for 1 hour, air dried and exposed to X-ray film.

Binding of plasmids to nitrocellulose.We used plasmid pSV-jun and GAPDH gene in the experiment. The plasmids were first linearized with appropriate restriction enzymes and denatured with $0.2 \mathrm{M} \mathrm{NaOH}$ for 30 minutes at room temperature, and by neutralized with 10 volumes of $6 \mathrm{X} \mathrm{SSPE}$ at $0^{\circ} \mathrm{C}$. Twenty $\mu \mathrm{g}$ of DNA in each well was spotted onto nitrocellulose membrane using dot blot apparatus. The nitocellulose membrane was then baked at $80^{\circ} \mathrm{C}$ for 2 hours and stored for further use. 


\section{RESULTS}

Treatment of quiescent, serum-starved Balb/c 3T3 fibroblasts with $25 \mathrm{ng} / \mathrm{ml}$ of IGF I results in an increase in $c$-jun mRNA levels within 30 minutes. The levels of stimulation are about two folds higher than those in uninduced cells (Fig. 1, lanes 1, 2; Fig. 2c). Both c-jun species of 2.6-2.7 kb and a $3.4 \mathrm{~kb}$ precursor (15) can be induced by IGF I (Fig. 1). We used GAPDH as an internal control to ensure that equal amounts of RNA were loaded in each well.

Addition of IGF I in the presence of cycloheximide led to an induction of $c$-jun mRNA about 5 folds higher than that observed in the absence of the protein synthesis inhibitor (Fig. 1, lanes 2, 4; Fig. 2c). Our observation is consistent with the induction by serum as described by Ryseck et al. (14) and the induction by epidermal growth factor (EGF) as reported by Quantin and Breathnach (15). This supports the notion that several growth factors may share the common signal transduction pahtways. The super-induction of $c$-jun by IGF I plus cycloheximide shown in Fig. 1 indicates that the stimulation is a primary response.

The levels of c-jun RNA during G0/S transition state after stimulation by IGF I were examined by Northern analyses. Total RNA at different time point after IGF I stimulation in the absence and presence of cycloheximide were analyzed. The results showed that in the absence of protein synthesis inhibitor the stimulatory effect of IGF I was first observed in 30 minutes after stimulation (Fig. 2a). The peak of $c$-jun transcripts persisted for about 120 minutes and reached the maximal amount for about 60 minutes after

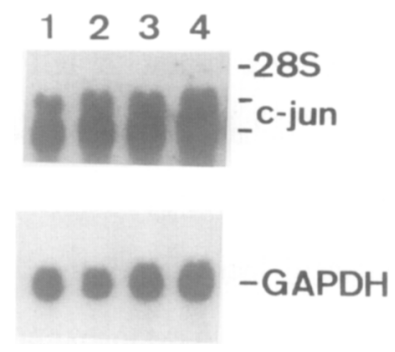

Eigel Induction of $c$-jun mRNA in quiescent Balb/c 3T3 cells stimulated by IGF I.

Northern blot of RNA from Balb/c 3T3 cells with different treatments. The blot was hybridized with $c$-jun and GAPDH probes. Lane 1 shows total RNA isolated from cells synchronized at quiescent stage. In lane 2, RNA was isolated from quiescent cells after 30 minutes of IGF I $(25 \mathrm{ng} / \mathrm{ml})$ treatment. Quiescent cells in lane 3 had been treated with cycloheximide $(10 \mu \mathrm{g} / \mathrm{ml})$ for 1 hour. The cells in lane 4 were treated with cycloheximide as in lane 3 and further subjected to IGF I stimulation for a period of 30 minutes. 

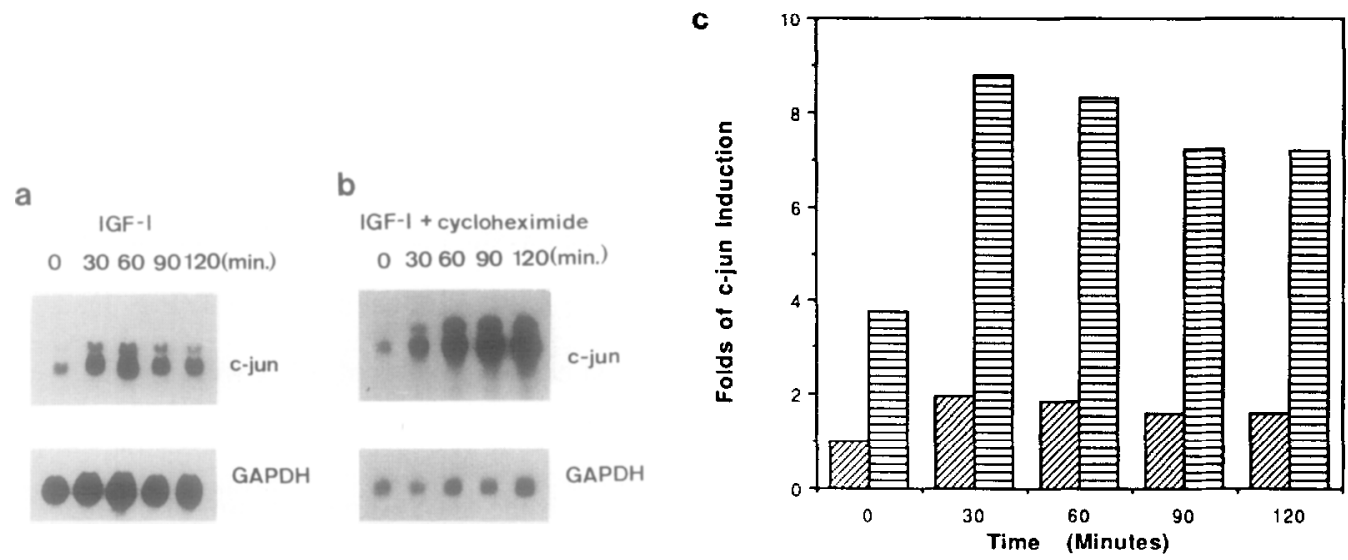

Eig.2 Kinetics of $c$-jun mRNA induction in IGF I stimulated Balb/c 3T3 cells.

Northern blot of RNA from Balb/c 3T3 cells treated with IGF I or IGF I plus cycloheximide harvested at different time point.

a. Total RNA $(10 \mu \mathrm{g})$ isolated from quiescent cells incubated with IGF I for different times.

b. Total RNA $(10 \mu \mathrm{g})$ isolated from quiescent cells pretreated with cycloheximide for 1 hour and incubated with IGF I for different times.

c. Northern blots in Fig. $2 \mathrm{a}$ and $2 \mathrm{~b}$ quantified by densitometry scanning. The $c-j u n$ mRNA levels from IGF I-treated cells ( $\boldsymbol{B}$ ) and from IGF V/cycloheximide-treated cells (目) are compared.

stimulation ( Fig. 2a). Addition of IGF I to serum starved quiescent cells caused a 2 -fold elevation of $c$-jun mRNA in comparison with basal level expression (Fig. 2c). In the presence of both cycloheximide and IGF $I$, the transcripts of $c$-jun not only increased within 30 minutes but maintained at high levels for a period of at least 2 hours (Fig. 2b).

To determine whether the effects of IGF I on $c$-jun transcript were due to transcriptional activation of the gene, nuclear run-off analyses were performed as described. To our surprise, we found that IGF I did not activate the transcription of $c$-jun in quiescent cells because only low amounts of newly synthesized $c$-jun mRNA were found in both quiescent cells and cells treated with IGF I alone (Fig. 3 lanes 1, 2). Cycloheximide, by itself, showed stimulatory effect on the synthesis of $c$-jun mRNA (Fig. 3, lane 3). Furthermore, while the cells were treated with both cycloheximide and IGF I, the transcription of $c$-jun dramatically increased (Fig. 3, lane 4). In comparison with cells treated with IGF I only, the presence of both cycloheximide and IGF I showed synergistic stimulation on $c$-jun transcripiton (Fig. 3, lanes 2, 4).

Since IGF I activated $c$-jun transcription efficiently only in the presence of cycloheximide, the increase of $c$-jun mRNA observed in Northem blot analysis of IGF I stimulated cells (Fig. 1, Fig. 2) could be caused by stabilization of pre-existing transcripts. 


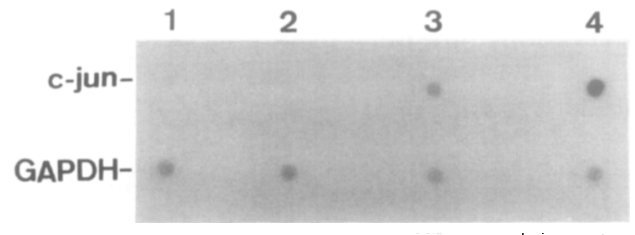

Eig.3 Nuclear Run-off analysis of $c$-jun mRNA.

Nuclei were isolated from quiescent cells (lane 1) or cells stimulated with IGF I for 30 minutes in the absence (lane 2) or presence (lane 4) of cycloheximide. Lane 3 contained transcripts of nuclei isolated from quiescent cells treated with cycloheximide only.

By examining the stability of $c$-jun mRNA in IGF I-treated cells, we observed that $c$-jun mRNA was more stable than that of quiescent cells (Fig. 4). The half life of $c$-jun mRNA was found to be increased by 30 minutes by IGF I treatment. (Fig. 4c)

\section{DISCUSSION}

In this study we demonstrated that IGF I was able to increase the $c$-jun mRNA level in Balb/c 3T3 cells up to 2 folds within 30 minutes. Nuclear run-off analyses revealed that IGF I alnone did not stimulate $c$-jun transcription but would cause a dramatic increase in $c$ jun mRNA level only if the protein synthesis was blocked by cycloheximide. Cycloheximide was also shown to stimulate $c$-jun mRNA synthesis, as has been well-
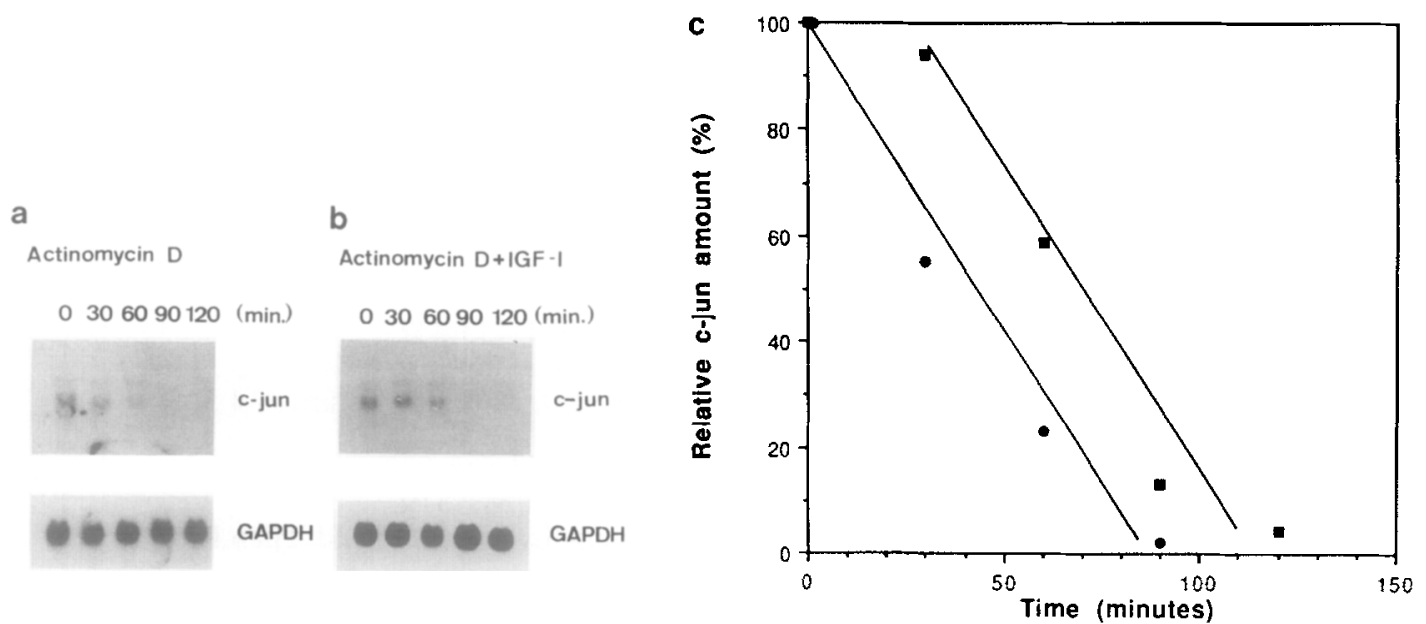

Fig.4 Stability of $c$-jun mRNA after IGF I stimulation.

Quiescent Balb/c 3T3 cells were treated with actinomycin D $(1 \mu \mathrm{g} / \mathrm{ml})$ for 15 minutes before IGF I stimulation. RNA was isolated at indicated time points after administration of growth factor. The level of $c$-jun mRNA was determined by Northern blotting analysis. Ten micrograms of cellular RNA was used in each lane in $a$ and $b$.

a. Levels of $c$-jun mRNA at different time points after actinomycin D treatment.

b. Levels of $c$-jun mRNA at different time points after actinomycin D and IGF I treatment.

c. Quantification of Northern blottings in Fig. 4a.(O) and Fig. 4b.(口) The levels of $c$-jun mRNA were normalized with respect to GAPDH. 
documented. These observations prompted us to hypothesize that the $c$-jun mRNA levels may be regulated by some transciptional repressors and nucleases whose functions are modulated by IGF I. In the quiescent state, the repressors may be switched to active form to repress the $c$-jun transcription. IGF I treatment would inactivate the repressors and at the same time reduce the nuclease activity via post-translational modification (33). The synergistic effects by IGF I and cycloheximide on $c$-jun mRNA level and the stabilization of $c$-jun mRNA by IGF I reported herein indicate that IGF I affects $c$-jun expression by transciptional activation and stabilization of the existing transcripts.

\section{ACKNOWLEDGMENTS}

We thank Dr. Ming-Derg Lai for the kind gift of $c-j u n$ and GAPDH cDNA. This work was supported by a grant (NSC 81-0211-B-001-06) from National Science Council, R.O.C.

\section{REFERENCES}

1. Scher, C.D., Stathakos, D., and Antoniades, H. N. (1974) Nature 247 279-281.

2. Antoniades, H.N., Stathakos, D., and Scher, C.D. (1975) Proc. Natl. Acad. Sci. USA 72 2635-2639.

3. Rinderknecht, E. and Humbel, R.E. (1978) J. Biol. Chem. 253 2769-2776.

4. Schoenle, E., Zapf, J., Humbel, R.E. and Froesch, E.R. (1982) Nature $296252-$ 253.

5. D'Ercole, A.J., Stiles, A.D. and Underwood, L.E. (1984) Proc. Natl. Acad. Sci. USA, 81 935-939.

6. Stiles, C.D., Capone, G.T., Scher,C.D., Antoniades, G.N.,Van Wyk, J.J.and Pledger, W.J. (1979) Proc. Natl. Acad. Sci. USA 76 1279-1283.

7. Sporn, M.B., and Roberts, A.B. (1988) Nature 332 217-219.

8. de Pablo, F. and Roth, J.(990) Trends Biochem. Sci. 15 339-342.

9. Cross, M. and Dexter, T.M. (1991) Cell 64 271-280.

10. Green, J.B.A., and Smith, J.C. (1991) TIG 7 245-250.

11. Hunter, T. (1991) Cell 64 249-270.

12. Greenberg, M.E. and Ziff, E.B. (1984) Nature 311 433-437.

13. Lau, L.F. and Nathans, D. (1987) Proc. Natl. Acad. Sci. USA 84 1182-1186.

14. Ryseck,R.-P., Hirai, S.I., Yaniv, M. and Bravo, R.(1988) Nature 334 535537.

15. Quantin, B., and Breathnach, R. (1988) Nature 334 538-539.

16. Herschman, H.R. (1991) Annu. Rev. Biochem. 60 281-319.

17. Bohmann,D., Bos,T.J., Admon, A., Nishimura,T.,Vogt,P.K. and Tjian,R.(1987) Science 238 1386-1392.

18. Angel,P., Allengretto,E.A.,Okino, S.T., Hattori,K., Boyle,W. J.,Hunter,T. and Karin,M. (1988) Nature 332 166-171.

19. Massagué, J. and Czech, M.P. (1982) J. Biol. Chem. 257 5038-5045.

20. Czech, M.P. (1989) Cell 59 235-238 (1989).

21. Condorelli, G., Formisano, P., Villone, G., Smith, R.J., and Beguinot, F. (1989) J. Biol. Chem. 264 12633-12638.

22. Kadowaki, T., Koyasu, S., Nishida, E., Tobe, K., Izumi, T., Takaku, F., Sakai., H., Yahara, I., and Kasuga, M. (1987) J. Biol. Chem. $2627342-7350$.

23. Burgering, B.M.T., Snijders, A.J., Maassen, J.A., van der Eb, A.J. and Bos, J.L. (1989) Mol. Cell Biol. 9 4312-4322.

24. Ong, J., Yamashita, S., and Melmed, S. (1987) Endocrinology 120 353-357. 
25. Chiu, R., Boyle, W.J., Meek, J., Smeal, T., Hunter, T., and Karin, M. (1988) Cell 54 541-552.

26. Sassone-Corsi, P., Ransone, L.J., Lamph, W.W., and Verma, I.M. (1988) Nature 336 692-695.

27. Hentze, M.W. (1991) Biochim. Biophy. Acta 1090 281-292.

28. Lee, H., Shaw, Y.T., Chiou, S.T., Chang, W.C., and Lai, M.D. (1991) FEBS Lett. 280 134-136.

29. Tso, J.Y., Sun, X.H., Kao, T.H., Reece, K.S., and Wu, R. Nucl. Acids Res. (1985) 13 2485-2502.

30. MacDonald, R.J., Swift, G.H., Przybyla, A.E., and Chirgwin, J.M. (1987) Meth. Enzymol. 152 219-227.

31. Maniatis,T., Frisch, E.F., and Sambrook, J.(1989) in Molecular Cloning : A Laboratory Manual. Cold Spring Harbor Laboratory, New York .

32. Ausubel, F.M., Brent, R., Kingston, R.E., Moore, D.D., Seidman, J.G., Smithe, J.A., Struhl, K. (1990) in Current Protocols in Molecular Biology. John Wiley \& Sons Inc., New York.

33. Zumstein, P., and Stiles,C.D. (1987) J. Biol. Chem. 262 11252-11260. 